\title{
IMPACT OF THERMAL FATIGUE ON YOUNG'S MODULUS OF EPOXY ADHESIVES
}

\author{
Mariusz Kłonica ${ }^{1}$ \\ 1 Department of Production Engineering, Faculty of Mechanical Engineering, Lublin University of Technology, \\ Nadbystrzycka 36, 20-618 Lublin, Poland, e-mail: m.klonica@pollub.pl
}

Received: 2015.09.21

Accepted: 2015.11.14

Published: 2015.12.04

\begin{abstract}
The following paper presents a comparative analysis of two epoxy-based adhesives: Hysol 9466 and Hysol 3421, prior to and after thermal shock testing. The tests focused on determining Young's modulus. Epoxy-based materials are among the most widespread adhesive materials used as universal structural adhesives. The prepared epoxy samples (Hysol 9466 and Hysol 3421) were subjected to thermal shock cycling tests, according to a specified programme, in a thermal shock testing chamber, at a temperature range $-40{ }^{\circ} \mathrm{C}$ to $+60{ }^{\circ} \mathrm{C}$ and in the number of 200 cycles. Conclusions from the tests are presented at the final stage of the paper.
\end{abstract}

Keywords: Young’s modulus, epoxy adhesive, Hysol 9466, Hysol 3421, thermal shock

\section{INTRODUCTION}

Adhesive joining, and particularly gluing, sealing and airtight sealing of structures, are in constant development due to advances in chemistry of adhesive materials $[1,2,5,8]$. The use of adhesive joining in different branches of industry is continually spreading. While numerous factors contribute to this situation, it is predominantly the increased effectiveness of adhesive joining offered by modern fast-cure adhesives that plays a key role in this development.

The selection of adhesives is a difficult task, requiring extensive experience. Even adhesives of the same chemical type, such as epoxy adhesives (Hysol 9466 and Hysol 3421 [10, 11]), could considerably differ in terms of properties (elasticity, shrinkage during curing or strength at full cure). These factors determine the effectiveness of adhesive joining and strength of joint, particularly in extended work life of the structures in changing conditions $[3,4,7]$.

Problems connected with thermal fatigue (thermal shock) of adhesive bonds, especially adhesive joints, and the impact of this phenomenon on long-term safe operation of such structures is under constant analysis, whereas the results are burdened by certain risk. This results from many factors $[6,9]$ contributing to adhesive and cohesive strength of such joints.

\section{TEST MATERIAL AND METHODOLOGY}

Figure 1 shows moulded Hysol 9466 and Hysol 3421 epoxy adhesive test specimens which were subjected to thermal loading. Both the shape and size of specimens conform curent standards for the determination of mechanical properties of materials. The specimens were formed in a silicone mould. In order to obtain samples of required thickness, the specimens were subjected to milling in a vertical machining centre VMC $800 \mathrm{HS}$ with Heidenhain iTNC $530 \mathrm{CNC}$ system. The machining process was performed with a solid carbide (grade H10) milling cutter produced by Mapal.

Both epoxy adhesives (Hysol 9466 and Hysol 3421) were cured for 120 hours at ambient temperature in the range of $20-22{ }^{\circ} \mathrm{C}$ and relative humidity $34-42 \%$.

Table 1 presents the dimensions of the specimens, made of two epoxy adhesives: Hysol 9466 


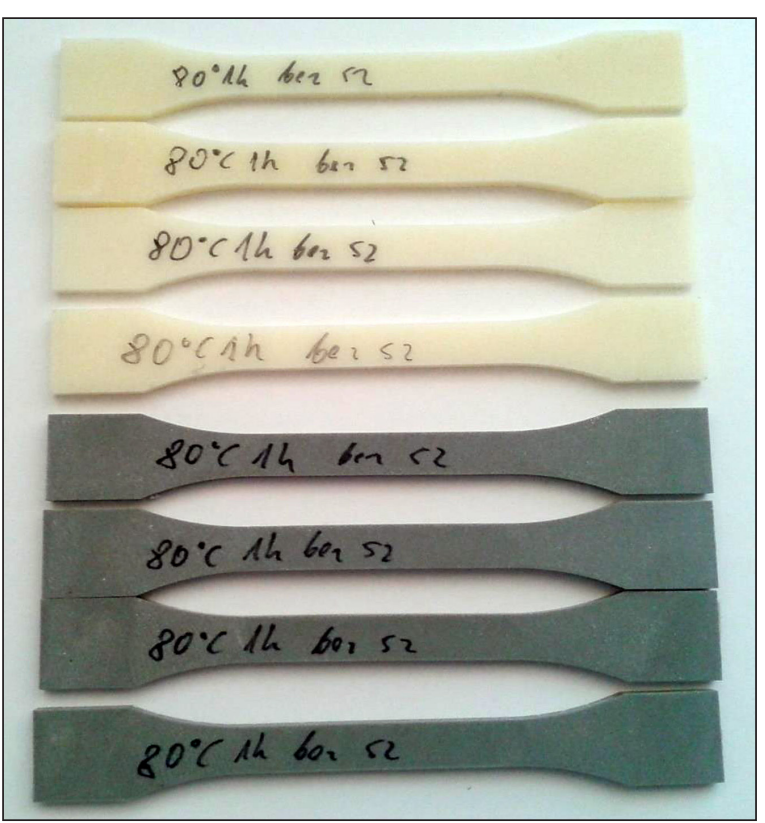

Fig. 1. Epoxy adhesive test specimens

Table 1. Transverse dimensions of test specimens with determined standard deviation

\begin{tabular}{|c|c|c|c|c|}
\hline \multirow{2}{*}{ Parameter } & \multicolumn{4}{|c|}{ Surface area [mm²] } \\
\cline { 2 - 5 } & \multicolumn{2}{|c|}{ Hysol 9466 } & \multicolumn{2}{c|}{ Hysol 3421 } \\
\cline { 2 - 5 } & $\begin{array}{c}\text { before } \\
\text { "thermal } \\
\text { shock" }\end{array}$ & $\begin{array}{c}\text { after } \\
\text { "thermal } \\
\text { shock" }\end{array}$ & $\begin{array}{c}\text { before } \\
\text { "thermal } \\
\text { shock" }\end{array}$ & $\begin{array}{c}\text { after } \\
\text { "thermal } \\
\text { shock" }\end{array}$ \\
\hline Average & 44.6 & 44.4 & 42.4 & 41.8 \\
\hline $\begin{array}{l}\text { Standard } \\
\text { deviation }\end{array}$ & 3.507 & 2.302 & 4.722 & 4.025 \\
\hline
\end{tabular}

and Hysol 3421. Standard deviation was accepted as the measure of dispersion. The dispersion of surface area of the analysed specimens was satisfactory after cutting them to the desired thickness.

Figure 2 shows the specimens gripped in a Zwick/Roell material testing machine Z150. Young's modulus was determined with an extensometer. The tests were conducted with conformity to DIN EN ISO 527-1 norm. The initial load during the test was equal to $0.1 \mathrm{MPa}$, the gauge length was equal to $110 \mathrm{~mm}$ and the standard travel length was $50 \mathrm{~mm}$.

The epoxy specimens (Hysol 9466 and Hysol 3421) were subjected to thermal fatigue cycling tests, according to a specified programme, in the thermal shock testing chamber, at a temperature range $-40{ }^{\circ} \mathrm{C}$ to $+60{ }^{\circ} \mathrm{C}$ and in the total number of 200 cycles. The range of temperatures set in tests is typical for the operating conditions of machines, including aircrafts.

Figure 3 shows the cycle of thermal loading (thermal shocks) applied to the test specimens; 200 cycles were realised. The bottom value of

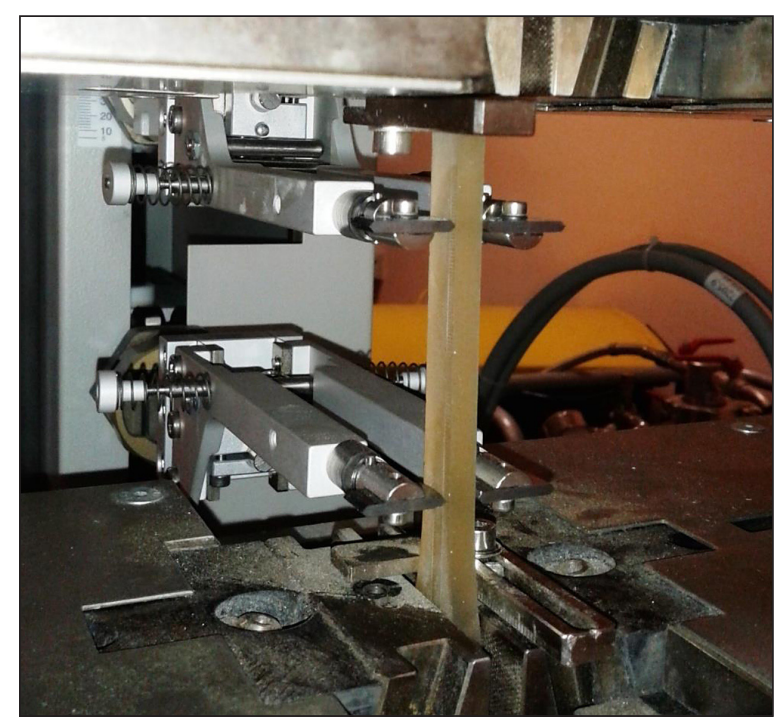

Fig. 2. Young's modulus determination

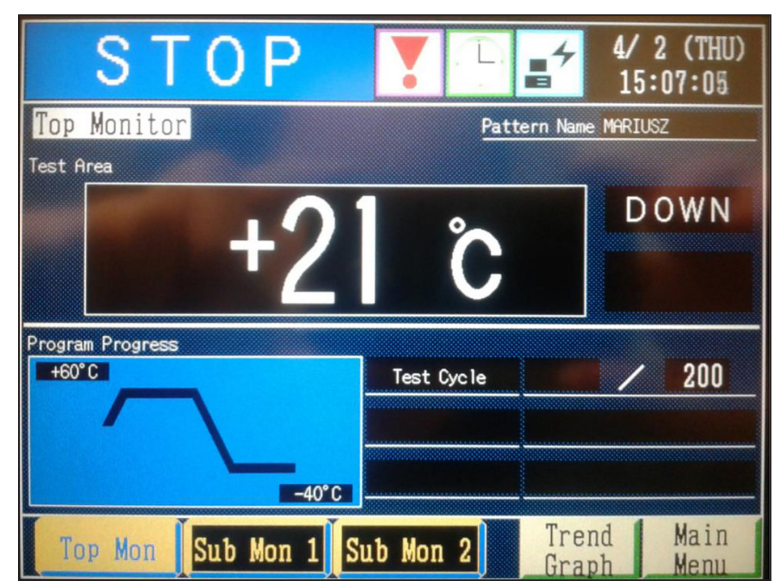

Fig. 3. Cycle of thermal loading during tests

temperature was set to $-40{ }^{\circ} \mathrm{C}$, while the top temperature value was equal to $+60{ }^{\circ} \mathrm{C}$. The conditioning time for each temperature was 15 minutes, excluding the time required for the stabilisation of temperature.

The main objective of the conduced tests was to determine the impact of heat loading (fatigue) on the value of Young's modulus of epoxy adhesives (Hysol 9466 and Hysol 3421).

\section{RESULTS}

Figure 4 shows the correlation between thermal fatigue (thermal shocks) and the value of Young's modulus of epoxy adhesives (Hysol 9466 and Hysol 3421).

The conducted tests indicate that the value of Young's modulus decreases with thermal fatigue, which is observed in both tested adhesives Hysol 9466 and Hysol 3421, and confirmed by compar- 


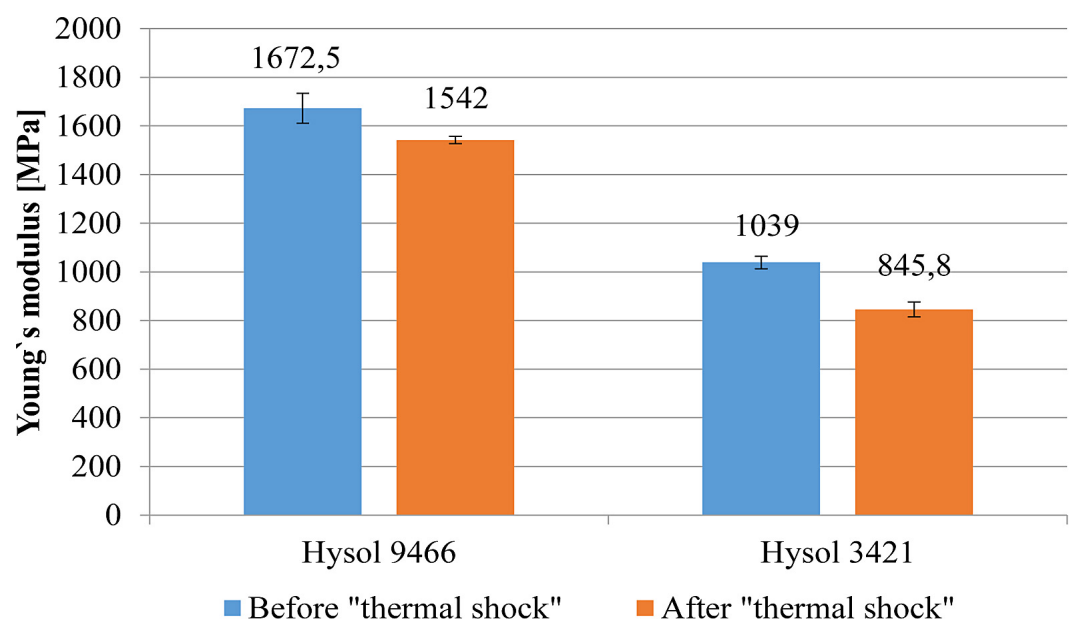

Fig. 4. Impact of thermal fatigue on Young's modulus

ison to specimens prior to thermal fatigue test. Young's modulus for Hysol 9466 adhesive was $8 \%$ lower than before thermal shocks. Standard deviation for specimens after thermal shocks was three-fold lower than in the case of specimens before thermal fatigue testing. Standard deviation for Hysol 3421, however, remained on the same level in both cases (before and after thermal loading). Similarly as in the case of the former adhesive, here as well after thermal loading, Young's modulus dropped by $20 \%$.

The analysis of results obtained in tests evidently shows a significant impact of ther- mal treatment (200 cycles) on the Young's modulus of analysed adhesives, Hysol 9466 and Hysol 3421. Figures 5 and 6 show changes of critical stresses in the analysed Hysol 9466 epoxy adhesive before and after thermal fatigue testing. Figures 7 and 8 show changes of critical stresses in the analysed specimens of Hysol 3421 epoxy adhesive before and after thermal shock.

The conducted tests showed that the traverse of the Zwick/Roell material testing machine Z150 at specimen failure was on a comparable level in all analysed cases.

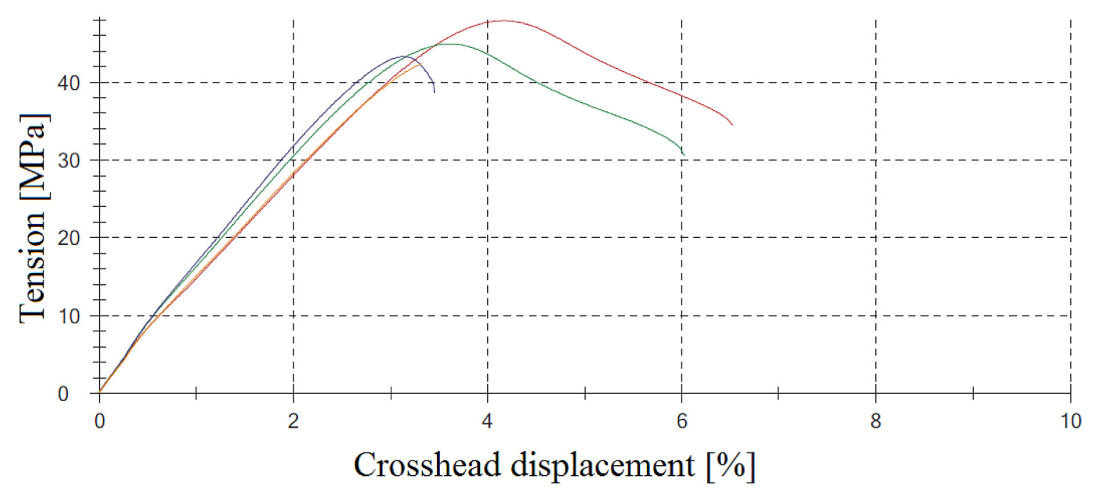

Fig. 5. Exemplary changes of critical stresses for Hysol 9466 specimens before thermal shock

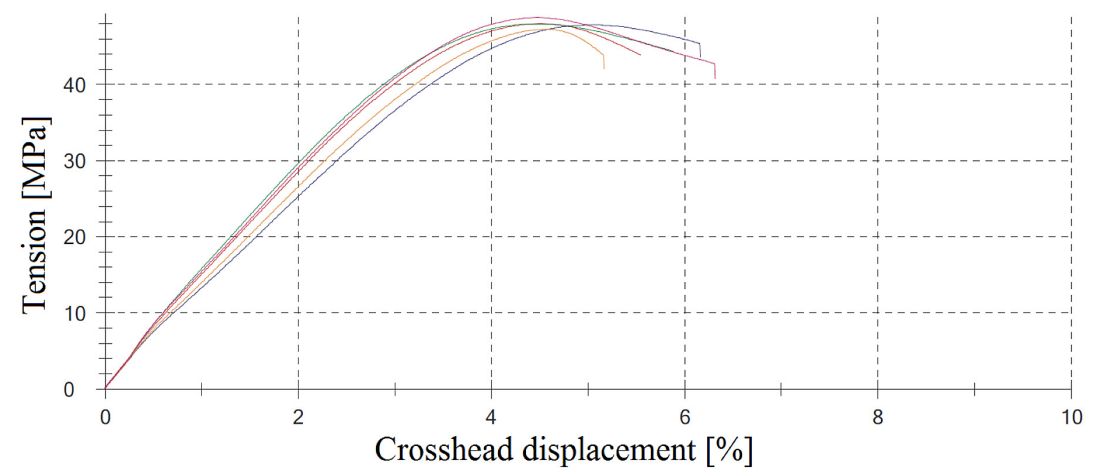

Fig. 6. Exemplary changes of critical stresses for Hysol 9466 specimens after thermal shock 


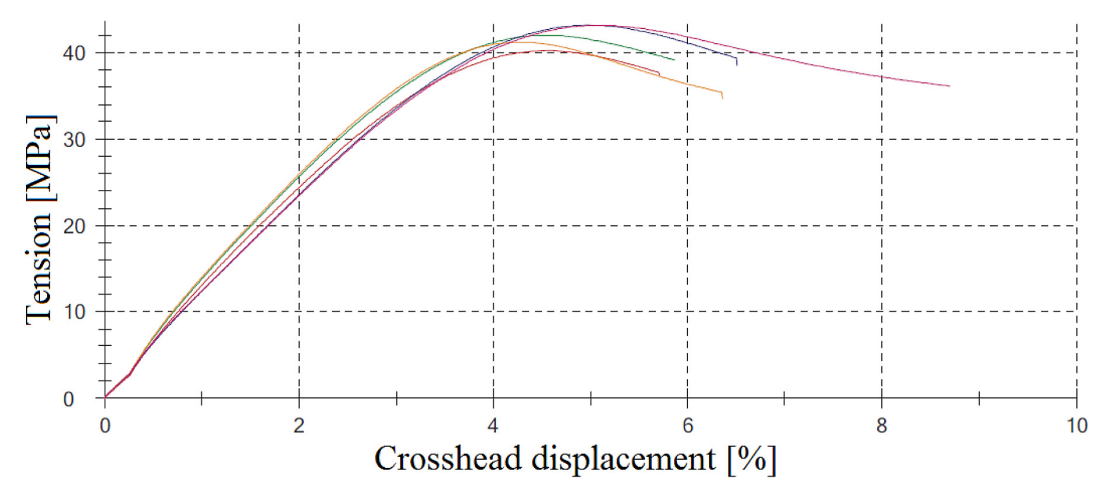

Fig. 7. Exemplary changes of critical stresses for Hysol 3421 specimens before thermal shock

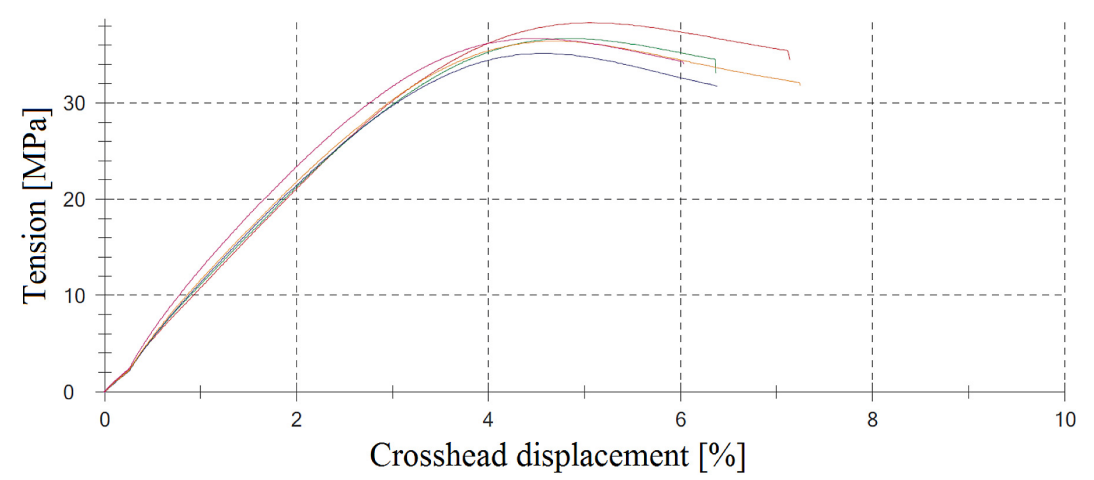

Fig. 8. Exemplary changes of critical stresses for Hysol 3421 specimens after thermal shock

\section{CONCLUSIONS}

The tests and analysis of its results allow the formulation of the following general conclusions:

1. Thermal shocks in 200 cycles exert a considerable impact on the values of Young's modulus of epoxy adhesives (Hysol 9466 and Hysol 3421).

2. The Young's modulus of epoxy adhesive Hysol 9466 after thermal shock is $8 \%$ lower than before thermal loading.

3. Thermal fatigue of Hysol 3421 epoxy adhesive brought about a $20 \%$ decrease in the value of Young's modulus, compared to before thermal loading.

4. The tests must be continued to determine the impact of other independent variables.

\section{REFERENCES}

1. Godzimirski J.: Wytrzymałość doraźna konstrukcyjnych połączeń klejowych. Wydawnictwo Naukowo-Techniczne, Warszawa 2002.

2. Godzimirski J., Komorek A.: Trwałość zmęczeniowa zakładkowych i czołowych połączeń klejowych. Przegląd Mechaniczny, 12, 2008, 40-44.

3. Kłonica M.: Comparative analysis of shear strength of single-lap adhesive joints after ,thermal shock". Applied Mechanics and Materials, 791, 2015, 224-231.

4. Kłonica M., Kuczmaszewski J., Samborski S.: Effect of a notch on impact resistance of the epidian 57/Z1 epoxy material after ,thermal shock”. Solid State Phenomena, 240, 2016, 161-167.

5. Kuczmaszewski J.: Fundamentals of metal-metal adhesive joint design. Politechnika Lubelska. Oddział PAN w Lublinie. Lublin 2006.

6. Kwiatkowski M.P., Kłonica M., Kuczmaszewski J., Satoh S.: Comparative analysis of energetic properties of Ti6Al4V titanium and EN-AW2017A(PA6) aluminum alloy surface layers for an adhesive bonding application. Ozone: Science \& Engineering: The Journal of the International Ozone Association, 35, 2013, 220-228.

7. Samborski S., Sadowski T.: Dynamic Fracture toughness of porous ceramics. The American Ceramic Society, 93(11), 2010, 3607-3609.

8. Żenkiewicz M.: Adhezja i modyfikowanie warstw wierzchniej tworzyw wielkocząsteczkowych. WNT, Warszawa 2000.

9. Żenkiewicz M.: Comparative study on the surface free energy of a solid calculated by different methods. Polymer Testing, 26, 2007, 14-19.

10. Card technology Loctite - Hysol $9466-07.2003$.

11. Card technology Loctite - Hysol 3421 - 24.01. 2003. 